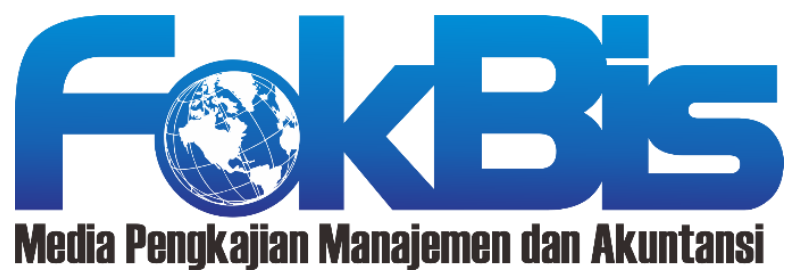

http://journal.stieputrabangsa.ac.id/index.php/fokbis/index

ISSN: 2623-2480/ P-ISSN: 1693-5209

\section{PENGARUH RASIO KINERJA KEUANGAN TERHADAP NILAI PERUSAHAAN BUMN NON-KEUANGAN DI BURSA EFEK INDONESIA}

\author{
Ahmad Azmy ${ }^{1}$, Vitriyani ${ }^{2}$ \\ 1,2, Tanri Abeng University, Indonesia \\ email: suyoto@ump.ac.id
}

\section{Article Information}

\section{History of Article:}

Received August $2^{\text {nd }}, 2019$

Accepted October $30^{\text {th }}, 2019$

Published December 23 ${ }^{\text {rd }}, 2019$

\section{DOI:}

10.32639/fokusbisnis.v\%vi\%i.322

\begin{abstract}
This study aims to determine the effect of the Financial Performance Ratio on the value of non-financial BUMN companies that are publicly listed on the Indonesia Stock Exchange. The data used are financial statements for 5 years starting from January 2012 to December 2016. This research is included in the association research which is to find out the effect of the independent variables on firm value. This research based on the results of testing the hypothesis partially on the T-Test, shows that Return On Assets (ROA) and Earning Per Share (EPS), affect the value of the company, while the Debt to equity ratio (DER) and Price Earning Ratio (PER) do not affect the value of the company. The results of the research in testing the hypothesis simultaneously on the F-Test show that the independent variables influence the value of the company.
\end{abstract}

Keywords: Financial Performance, Corporate Value

\title{
PENDAHULUAN
}

Persaingan bisnis di berbagai sektor menuntut perusahaan untuk lebih memacu dan mengembangkan perusahaan untuk mencapai tujuan yang diinginkan. Menurut teori perusahaan (theory of the firm) tujuan normatif perusahaan yang telah go public adalah meningkatkan kemakmuran pemilik atau para pemegang saham melalui peningkatan nilai perusahaan (Salvatore, 2005). Perusahaan melalui manajer keuangan harus mampu menjalankan fungsinya dalam mengelola keuangan dengan efektif dan seefisien mugkin. Alat yang digunakan untuk mengukur kinerja keuangan perusahaan secara komprehensif, yaitu ROA (Return on Assets).

Return on Assets (ROA) merupakan salah satu bentuk dari rasio profitabilitas untuk mengukur kemampuan perusahaan, dalam menghasilkan laba dengan menggunakan total aktiva yang ada. ROA yang positif menunjukkan bahwa dari total aktiva yang digunakan untuk operasi perusahaan mampu memberikan laba bagi perusahaan, sebaliknya jika ROA negatif menunjukkan total aktiva yang digunakan 
tidak memberikan keuntungan. Rasio kedua yang digunakan yaitu debt to equity ratio (DER). DER merupakan rasio yang membandingkan total utang dengan ekuitas (Kasmir, 2013). Rasio ini mengukur seberapa jauh perusahaan dibiayai oleh hutang, dimana semakin tinggi rasio ini menggambarkan gejala yang kurang baik bagi perusahaan. Semakin besar hutang dibanding modal sendiri semakin besar pula risiko keuangan yang akandihadapi investor sehingga investor cenderungmensyaratkan tingkat keuntungan yang semakin tinggi. Penggunaan hutang yang tinggi cenderung menimbulkan beban tetap yang ditanggung perusahaan sehingga menurunkan laba perusahaan sehingga menurunkan nilai perusahan di mata investor.mereka merasa bangga karena dirinya terlibat secara aktif sebagai bagian dari anggota organisasi tersebut.

Rasio ketiga yaitu Earnings per Share (EPS), Earning per share merupakan rasio yang menunjukkan berapa besar keuntungan yang diperoleh investor atau pemegang saham per lembar saham (Darmadji, 2012). Rasio ini digunakan untuk menilai potensi pendapatan per lembar saham yang bisa digunakan oleh pimpinan perusahaan. Manfaat dari rasio ini untuk mengetahui bagaimana perkembangan perusahaan dan peningkatan laba secara total. Hasil penghitungan rasio Earnings per Share (EPS) digunakan untuk memprediksi kemampuan perusahaan dalam menghasilkan laba di masa yang mendatang. Rasio yang terakhir yaitu Price Earnings Ratio (PER). PER merupakan indikasi penilaian pasar modal terhadap kemampuan perusahaan dalam menghasilkan laba/keuntungan potensial perusahaan di masa datang. Rasio ini menunjukkan seberapa banyak investor bersedia membayar untuk setiap laba yang dilaporkan (Brigham dan Houston, 2011). Price Earning Ratio adalah suatu rasio sederhana yang diperoleh dengan membagi harga pasar suatu saham dengan Earnings per Share. Jika Price Earning Ratio perusahaan tinggi berarti saham perusahaan dapat memberikan return yang besar bagi investor. Price Earning Ratio juga merupakan ukuran untuk menentukan bagaimana pasar memberi nilai atau harga pada saham perusahaan (Arisona, 2013).

\section{Teori Agensi}

Merupakan konsep yang menjelaskan hubungan kontaktual antara pemegang saham (principals) dan agents. Pihak principals adalah pihak yang memberikan manfaat kepada pihak lain, yaitu agent, untuk melakukan semua kegiatan atas nama principals dalam kapasitasnya sebagai pengambil keputusan (Jensen dan Smith, 1984). Tujuan dari teori agensi adalah, pertama, untuk meningkatkan kemampuan individu (baik principal maupun agen) dalam mengevaluasi lingkungan dimana keputusan harus diambil (the beliefs revision role). Kedua, untuk mengevaluasi hasil dari keputusan yang telah diambil guna mempermudah pengalokasian hasil antara principal dan agen sesuai dengan kontrak kerja (the performance evaluation role).

\section{Teori Sinyal}

Menjelaskan mengapa perusahaan mempunyai dorongan untuk memberikan informasi laporan keuangan pada pihak eksternal secara sukarela. Dorongan perusahan untuk memberikan informasi karena terdapat asimetri informasi antara perusahaan dan pihak luar karena perusahan mengetahui lebih banyak mengenai perusahan dan prospek yang mendatang dari pada pihak luar (investor, kreditor). Teori sinyal mengemukakan tentang bagaimana seharusnya sebuah perusahan memberikan sinyal kepada penguna laporan keuangan. Sinyal ini berupa informasi mengenai apa yang sudah dilakukan oleh manajemen untuk merealisasikan keinginan pemilk. Sinyal dapat berupa promosi atau informasi lain yang menyatakan bahwa perusahan tersebut lebih baik daripada perusahan lain (Azli \& Azizi, 2009).

\section{Stakeholder Theory}

Merupakan kumpulan kebijakan dan praktik yang berhubungan dengan stakeholder, nilai-nilai, pemenuhan ketentuan hukum, penghargaan masyarakat dan lingkungan, serta komitmen dunia usaha untuk berkontribusi dalam pembangunan secara berkelanjutan. Solihin (2012) menjelaskan bahwa 
stakeholder dibagi dalam dua kategori Inside-stakeholders dan Outside-stakeholders. Inside stakeholders, terdiri atas orang-orang yang memiliki kepentingan dan tuntutan terhadap sumber daya perusahaan serta berada di dalam organisasi perusahaan. Pihak-pihak yang termasuk dalam kategori inside-stakeholders ini adalah pemegang saham (stockholders), manajer, dan karyawan. Outside stakeholders adalah sekelompom orang yang terdiri atas orang-orang maupun pihak-pihak yang bukan pemilik perusahaan, pemimpin perusahaan, dan karyawan perusahaan. Akan tetapi memiliki kepentingan terhadap perusahaan dipengaruhi oleh keputusan serta tindakan yang dilakukan oleh perusahaan.

\section{Return on Assets}

Rasio ini mengukur kemampuan menghasilkan laba dari total aktiva yang digunakan (Wiagustini, 2014). Setiap perusahaan berusaha agar nilai dari ROA mereka tinggi. Semakin besar nilai dari ROA itu berarti bahwa semakin baik perusahaan menggunakan assetnya untuk mendapat laba, dengan meningkatnya nilai ROA profitabilitas dari perusahaan semakin meningkat (Arista, 2012). Hal ini membuat investor menjadi tertarik untuk membeli saham perusahaan serta berdampak pada harga saham yang semakin meningkat dan diikuti dengan tingkat pengembalian return saham yang tinggi. Mardiyanto (2009) menjelaskan bahwa Return on Assets (ROA) adalah Rasio untuk menghitung perbandingan antara laba bersih dengan total aktiva perusahaan.

\section{Debt to Equity Ratio}

Menurut Kasmir (2013) menjelaskan bahwa Debt Equity Ratio (DER) merupakan rasio yang digunakan untuk menilai hutang dengan ekuitas. Rasio ini dicari dengan cara membandingkan antara seluruh hutang, termasuk hutang lancar dengan seluruh ekuitas. Rasio ini berguna untuk mengetahui jumlah dana yang disediakan peminjam dengan pemilik peerusahaan. Meilani (2014) menjelaskan Debt Equity Ratio (DER) berfungsi untuk mengukur jumlah hutang atau pendanaan dari luar perusahaan terhadap modalsendiri (Sharehohder equity).

\section{Earnings per Share}

Menurut Fahmi (2012) menjelaskan Earnings per Share (EPS) adalah bentuk pemberian keuntungan yang diberikan kepada pemegang saham dari setiap lembar saham dari setiap lembar saham yang dimiliki. Syamsudin (2011) menyatakan bahwa: Pada umumnya manajemen perusahaan, pemegang saham biasa dan calon pemegang saham sangat tertarik terhadap EPS.

\section{Price Earning Ratio}

Price Earning Ratio merupakan bagian dari rasio penilaian untuk mengevaluasi laporan keuangan. Price Earning Ratio dihitung dari perbandingan antara harga saham suatu perusahaan dengan laba per lembar saham. Harga pasar saham adalah harga jual dari investor yang satu kepada investor yang lain setelah saham tersebut dicatatkan di bursa, baik bursa utama maupun Over The Counter Market. (Widoatmodjo, 2012).

\section{Nilai Perusahaan}

Memaksimalkan nilai perusahaan sangat penting bagi suatu perusahaan, karena dengan memaksimalkan nilai perusahaan berarti juga memaksimalkan kemakmuran pemegang saham yang merupakan tujuan utama perusahaan (Taswan, 2010). Semakin tinggi harga saham semakin tinggi pula nilai perusahaan. Nilai perusahaan yang tinggi akan membuat pasar percaya tidak hanya pada kinerja perusahaan saat ini namun juga pada prospek perusahaan dimasa depan. Nilai perusahaan akan tercermin dari harga sahamnya. Harga pasar dari saham perusahaan yang terbentuk antara pembeli dan penjual disaat terjadi transaksi disebut nilai pasar perusahaan, karena harga pasar saham dianggap cerminan dari nilai aset perusahaan sesungguhnya. Jadi dengan penjelasan dari teori yang digunakan dalam penelitian ini. Maka dibuat 
kerangka konseptual yang digunakan untuk menghubungkan antara variabel-variabel penelitian, yaitu variabel dependen dan variabel independen.

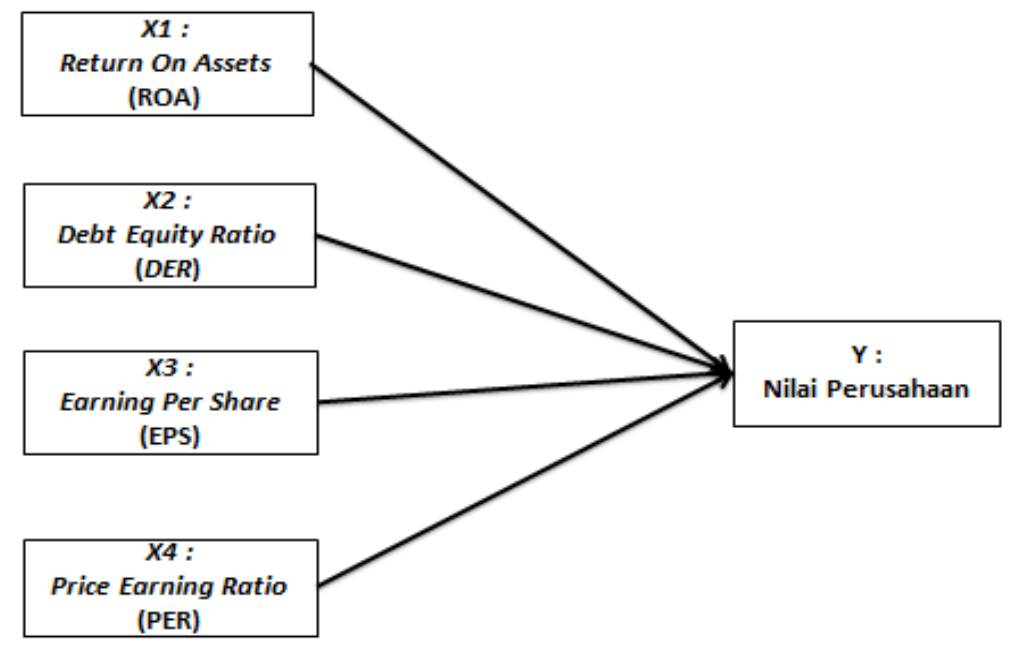

Gambar 1. Model Penelitian

Dari kerangka konseptual diatas dapat dilihat bahwa ada empat variabel independen yaitu ROA, DER, EPS, dan PER dan satu variabel dependen yaitu nilai perusahaan. Dari kerangka konseptual diatas dapat dirumuskan persamaan regresi dibawah ini adalah sebagai berikut :

$Y=a+{ }_{\beta 1} X_{1}+{ }_{\beta 2} X_{2}+{ }_{\beta 3} X_{3}+{ }_{\beta 4} X_{4}+e$

Keterangan :

$\mathrm{Y}=$ Nilai perusahaan

$\mathrm{X} 1=$ Return On Assets (ROA)

$\mathrm{X} 2$ = Debt to Equity Ratio (DER)

X3 = Earning Per Share (EPS)

$\mathrm{X} 4$ = Price Earning Ratio (PER)

$\mathrm{e}=$ error term

Berdasarkan penjelasan diatas bahwasanya rasio-rasio tersebut dapat memperlihatkan tingkat dari nilai perusahaan. Nilai perusahaan merupakan kondisi tertentu yang telah dicapai oleh suatu perusahaan sebagai gambaran dari kepercayaan masyarakat terhadap perusahaan setelah melalui suatu proses kegiatan selama beberapa tahun, yaitu sejak perusahaan tersebut didirikan sampai dengan saat ini. Meningkatnya nilai perusahaan adalah sebuah prestasi, yang sesuai dengan keinginan pemilik perusahaan. Ini disebabkan peningkatan nilai perusahaan sejalan dengan kesejahteraan dan pencapaian target bisnis secara komprehensif. Studi empiris pada penelitian ini adalah perusahaan Badan Usaha Milik Negara (BUMN) 


\section{METODE PENELITIAN}

\section{Populasi dan Sampel}

Populasi dalam penelitian ini adalah 16 perusahaan besar BUMN non keuangan yang telah go-public di Bursa Efek Indonesia. Sampel adalah bagian dari jumlah dan karakteristik yang dimiliki oleh populasi tersebut (Sugiyono, 2014). Adapun metode pemilihan sampel yang digunakan adalah purposive sampling yaitu pemilihan sampel tidak secara acak tetapi sesuai dengan kriteria tertentu. Adapun kriteria untuk penelitian ini adalah sebagai berikut:

1. Perusahaan BUMN non keuangan yang telah go-public di Bursa Efek Indonesia sejak tahun 2012 dan dan tetap terdaftar di Bursa Efek Indonesia tahun 2016, hal tersebut dimaksudkan supaya bisa mendapatkan data yang berkesinambungan dan lebih memudahkan dalam mengolah data.

2. Perusahaan menerbitkan annual report selama periode tahun penelitan yaitu tahun 2012-2016.

3. Perusahaan yang memiliki variabel yang digunakan selama periode penelitian yaitu tahun 20122016.

\section{Variabel Penelitian}

Variabel yang digunakan oleh penulis dalam penelitian ini terdiri dari variabel dependen dan variabel independen. Variabel dependen adalah variabel yang dijelaskan atau dipengaruhi oleh variabel independen. Variabel dependen pada penelitian ini adalah nilai perusahaan yang diproksikan dengan rasio Tobin's Q. Variabel independen adalah variabel yang menjelaskan atau mempengaruhi variabel yang lain. Variabel penelitian ini adalah Return on Assets (ROA), Debt to equity ratio (DER), Earning Per Share (EPS), dan Price Earning Ratio (PER).

\section{Jenis dan Sumber Data}

Jenis data yang digunakan dalam penelitian ini adalah data kuantitatif. Siregar (2013) menjelaskan bahwa data kuantitatif berupa angka dan dapat diolah atau dianalisis dengan menggunakan teknik perhitungan statistik. Jenis data penelitian ini merupakan data sekunder. Data sekunder merupakan sumber data penelitian yang diperoleh peneliti secara tidak langsung atau melalui media perantara (Indriantoro \& Supomo, 2009). Data tersebut berupa laporan keuangan tahunan perusahaan yang terdaftar di Bursa Efek Indonesia, khususnya neraca, laporan laba rugi, dan laporan perubahan laba ditahan. Data diambil dalam periode pengamatan antara tahun 2012-2016.

\section{Teknik dan Analisis Data}

Pengolahan data statistik memiliki peran yang sangat penting dalam suatu penelitian karena dari hasil pengolahan data akan kita dapatkan kesimpulan penelitian. Teknik pengolahan data mencakup perhitungan data analisis model penelitian. Sebelum membuat kesimpulan dalam suatu penelitian analisis terhadap data harus dilakukan agar hasil penelitian menjadi akurat. Maka penelitian ini dilakukan dengan metode statistik yang dibantu program EVIEWS 7. Penelitian ini dilakukan dengan tujuan untuk mengetahui pengaruh hubungan antara rasio kinerja keuangan yang diproksikan dengan variabel independen ROA, DER, EPS, dan PER dengan variabel dependen nilai perusahaan (Tobins' Q). Penelitian ini dilakukan dengan menggunakan analisis regresi linier berganda. Analisis regresi berganda digunakan untuk meramalkan pengaruh dua atau lebih variabel predictor (variabel bebas) terhadap satu variabel kriterium (variabel terikat) untuk membuktikan ada atau tidaknya hubungan fungsioanl antara dua buah variabel bebas $(X)$ atau lebih dengan sebuah variabel terikat (Y) (Akbar \& Usman, 2006).

Analisis data dalam penelitian ini menggunakan 4 uji yaitu uji normalitas data, uji multikolinieritas, uji heteroskedastisitas, dan uji autokorelasi. Uji normalitas data dilakukan untuk melihat kenormalan distribusi data, uji normalitas, data dalam penelitian ini dilihat dengan probability jarque-Bera dengan 
menggunakan eviews 7. Data dikatakan normal apabila nilai probability jarque-Bera setara atau lebih dari ketentuan yang ditetapkan yaitu 0,05. Uji multikolinieritas dilakukan untuk melihat apakah dalam model regresi ditemukan adanya korelasi antar variabel independen atau tidaknya. Data yang terbebas dari masalah multikolinearitas harus memiliki nilai correlations antar variabel independennya lebih kecil 0,8 (correlations $<0,8)$. Uji heteroskedastisitas bertujuan untuk melihat apakah setiap variabel pengganggu mempunyai variabel yang sama atau tidak, Untuk mengetahui ada tidaknya masalah ini akan dilakukan uji Breusch-Pagan-Godfrey, dengan bantuan softwere eviews 7. Untuk terbebas dari masalah uji ini nilai probabilitas Obs*R-squared harus lebih besar dari 0,05. Uji autokorelasi dilakukan untuk melihat ada atau tidaknya korelasi antar anggota sampel yang diuturkan berdasarkan waktu. Untuk melihat terjadi atau tidaknya autokorelasi dapat dilihat dengan menggunakan nilai durbin waston (DW), bila nilai DW terletak diantara angka $-2<$ DW $<2$ maka dapat dikatakan tidak terjadi autokorelasi.

\section{Pengujian Hipotesis}

Hipotesis penelitian diuji dengan menggunakan analisis regresi linier berganda. Pengujian dengan menggunakan uji statistik ini ditujukan untuk memberikan jawaban atas hipotesis yang diajukan, yaitu pengaruh langsung antara ROA (X1), DER (X2), EPS (X3) dan PER (X4) dengan Nilai Perusahaan (Y).

\section{HASIL DAN PEMBAHASAN}

\section{Uji Normalitas}

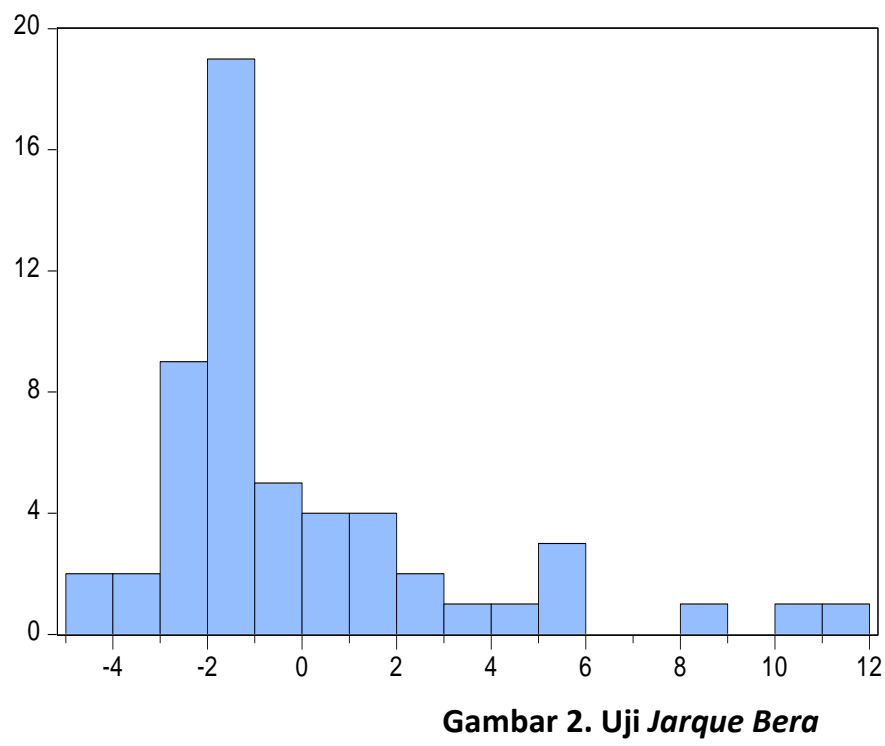

\begin{tabular}{|lr}
\hline \multicolumn{2}{|l}{ Series: Residuals } \\
Sample 155 \\
\multicolumn{2}{|l}{ Observations 55} \\
Mean & $-1.53 e-16$ \\
Median & -1.220295 \\
Maximum & 11.26168 \\
Minimum & -4.537887 \\
Std. Dev. & 3.353797 \\
Skewness & 1.678028 \\
Kurtosis & 5.535721 \\
& \\
Jarque-Bera & 40.54644 \\
Probability & 0.000000 \\
\hline
\end{tabular}

Berdasarkan tabel histogram dari uji normalitas diatas menjelaskan bahwa probability jarque-Bera sebesar 0,000 yang dimana nilai tersebut dibawah dari syarat atau ketentuan yaitu sebesar 0,05 untuk menjadikan data yang berdistribusi normal. Dengan demikian dapat disimpulkan bahwa dengan melihat probability jarque-Bera yang sangat rendah, data dikatakan tidak bisa berdistribusi secara normal. Ghozali (2013) menjelaskan bahwa untuk sampel yang besar terutama lebih dari 30 ( $n \geq 30$ ), distribusi sampel dianggap mendekati distribusi normal yang berarti bahwa walaupun dari pengujian asumsi klasik berupa pengujian normalitas menunjukkan bahwa ada data berdistribusi tidak normal namun karena observasi lebih dari $30(n \geq 30)$ maka data tersebut tetap dianggap normal. 


\section{Uji Multikolinearitas}

Tabel 1. Koefisien Antarvariabel Independen

\begin{tabular}{lllll}
\hline \multicolumn{1}{l}{ ROA } & DER & EPS & PER \\
\hline ROA & 1.000000 & -0.534500 & 0.507935 & 0.162962 \\
DER & -0.534500 & 1.000000 & -0.258774 & -0.059068 \\
EPS & 0.507935 & -0.258774 & 1.000000 & -0.202685 \\
PER & 0.162962 & -0.059068 & -0.202685 & 1.000000 \\
\hline
\end{tabular}

sumber: Data diolah, 2019

Berdasarkan tabel di atas dapat dilihat bahwa nilai koefisien korelasi antara sesama variabel independen yaitu terdiri dari ROA, DER, EPS, dan PER mempunyai nilai koefisien korelasi dibawah 0,8. Hal ini menunjukkan bahwa model yang digunakan tidak mengandung unsur multikolinearitas.

\section{Uji Heteroskedastisitas}

Tabel 2. Uji Breusch-Pagan-Gofrey

\begin{tabular}{|c|c|c|c|}
\hline F-statistic & 1.987389 & Prob. F(4,50) & 0.1108 \\
\hline $\begin{array}{c}\text { Obs*R- } \\
\text { squared }\end{array}$ & 7.544932 & $\begin{array}{c}\text { Prob. Chi- } \\
\text { Square(4) }\end{array}$ & 0.1097 \\
\hline $\begin{array}{c}\text { Scaled } \\
\text { explained SS }\end{array}$ & 14.14120 & $\begin{array}{c}\text { Prob. Chi- } \\
\text { Square(4) }\end{array}$ & 0.0069 \\
\hline
\end{tabular}

sumber: Data diolah, 2019

Berdasarkan Tabel 2 yang merupakan output dari uji Breusch-Pagan-Godfrey, dengan bantuan softwere eviews 7 dapat dilihat bahwa probabilitas Obs*R-squared lebih besar dari a $(0,1097>$ dari 0,05), maka HO diterima, artinya dalam penelitian ini terbebas dari masalah heterokedatisitas.

\section{Uji Autokorelasi}

Tabel 3. Uji Durbin Watson

\begin{tabular}{|c|c|}
\hline Nama Uji & Hasil \\
\hline Uji Durbin-Watson & 1.200277 \\
\hline
\end{tabular}

Santoso (2002) menjelaskan untuk mendeteksi terjadi autokorelasi atau tidak dapat dilihat melalui nilai durbin waston (DW), bila nilai DW terletak diantara angka $-2<\mathrm{DW}<2$ maka dapat dikatakan tidak terjadi autokorelasi. Berdasarkan output diatas dapat dilihat nilai DW adalah 1.200277. Dengan mengikuti ketentuan diatas dapat dikategorikan bahwa nilai DW (1.200277) berada diantara interval $-2<$ DW $<2$ sehingga tidak terjadi autokorelasi.

\section{Uji Koefisien Determinasi $\left(\mathbf{R}^{2}\right)$}

Jadi didapat satu model regresi dengan nilai koefisien detrminasi (Adjusted R-squared) sebesar 0.121835 (12,2\%). Koefisien determinasi ini menunjukkan bahwa 12,2\% nilai perusahaan dapat dijelaskan atau dipengaruhi oleh ROA, DER, EPS, dan PER. Sedangkan sisanya dipengaruhi oleh variabel lainnya yang tidak termasuk dalam model persamaan penelitian ini. 


\section{Uji t-Statistik}

Tabel 4 .Uji-t

\begin{tabular}{|l|l|l|l|l|l|}
\hline Variabel & Koefisien & Std. Error & t-Statistic & t- Tabel & Prob. \\
\hline C & 2.330644 & 1.352681 & 1.722981 & 2.008559 & 0.0911 \\
\hline ROA & 0.230643 & 0.089501 & 2.576997 & 2.008559 & 0.0130 \\
\hline DER & -0.114166 & 0.787334 & -0.145004 & 2.008559 & 0.8853 \\
\hline EPS & -0.004903 & 0.001670 & -2.936012 & 2.008559 & 0.0050 \\
\hline PER & $-1.55 E-05$ & $9.89 E-06$ & -1.563963 & 2.008559 & 0.1241 \\
\hline
\end{tabular}

sumber: Data diolah, 2019

\section{Pembahasan}

Dari hasil penelitian, terutama pengujian hipotesis, berikut disajikan diskusi dan pembahasan. Pantow et al (2015) dan Haryati \& Ayem (2014) menunjukkan bahwa Return On Assets (ROA) berpengaruh secara positif dan signifikan terhadap nilai perusahaan. Hasil penelitian ini mengkonfirmasi simpulan bahwa ROA berpengaruh signifikan terhadap nilai perusahaan. Hal ini mengindikasikan bahwa perusahaan yang baik memperoleh keuntungan maksimal dengan total aktiva yang dimiliki perusahaan. Sehingga semakin besar kemampuan perusahaan untuk menutup investasi yang digunakan dan memungkinkan perusahaan untuk dapat membiayai investasinya dari dana yang berasal dari sumber internal yang tersedia dalam bentuk laba ditahan. Hal ini menunjukkan bahwa ROA yang tinggi akan menjadi sinyal positif bagi investor yang dapat meningkatkan kemakmuran investor. Berdasarkan output regresi menunjukkan bahwa Debt to Equity Ratio (DER) tidak berpengaruh dan tidak signifikan terhadap nilai perusahaan. Hasil penelitian ini mengkonfirmasi hasil dari penelitian sebelumnya salah satunya Ayem dan Haryati (2014), Wulandari (2015) dan Haryadi \& Nuraeni (2016) yang menyebutkan bahwa Debt to Equity Ratio berpengaruh negatif dan tidak signifikan terhadap nilai perusahaan. Adanya hubungan negatif dari variabel leverage (DER) terhadap nilai menunjukan semakin naik leverage (DER) maka semakin turun nilai perusahaan dan tidak berpengaruh signifikan. Hal ini karena seberapapun banyaknya penggunaan hutang tidak akan berpengaruh terhadap harga saham dan nilai perusahaan karena penggunaan hutang akan menyebabkan biaya ekuitas biasa naik dengan tingkat yang sama.

Uji regresi Earnings per Share berpengaruh positif dan signifikan terhadap nilai perusahaan. Hasil tersebut mengkonfirmasi penelitian sebelumnya yaitu dari Permana (2010), Mindra \& Erawati (2014), dan Haryati \& Ayem (2014) yang mengatakan bahwa Earning per Share berpengaruh positif dan signifikan terhadap nilai perusahaan. Prasetyorini (2013) menunjukkan bahwa variabel PER berpengaruh positif dan signifikan terhadap Nilai Perusahaan. Hal ini sejalan dengan signalling theory, bahwa PER yang tinggi merupakan sinyal pertumbuhan pendapatan perusahaan dimasa yang akan datang. Sinyal tersebut akan ditanggap investor sebagai good news yang nantinya akan mempengaruhi persepsi investor terhadap kinerja perusahaan. Permintaan saham yang tinggi akan membuat para investor menghargai nilai saham lebih besar daripada nilai yang tercatat pada neraca perusahaan, sehingga PBV perusahaan tinggi dan nilai perusahaan pun tinggi.

\section{SIMPULAN}

Hasil uji regresi linier berganda ditemukan bahwa variabel independen berpengaruh secara simultan terhadap variabel dependen, yaitu ROA, DER, EPS, dan PER berpengaruh secara keseluruhan terhadap nilai perusahaan. 
Penelitian selanjutnya perlu untuk menambah atau mengganti beberapa variabel yang dimungkinkan berpengaruh terhadap nilai perusahaan seperti price book value (PBV), dividend payout ratio (DPR), kebijakan institusi (KI) dan lain sebagainya. Para investor diharapkan dapat memperhatikan variabel return on asset (ROA) dan earning per share (EPS) yang berpengaruh positif dan signifikan terhadap nilai perusahaan sebelum mengambil keputusandalam melakukan investasi di pasar modal. Peneliti selanjutnya diharapkan dapat memperbaiki nilai adjusted R2 dengan memasukkan variabel-variabel lain, sehingga diperoleh daya prediksi yang lebih baik. Menambah periode penelitian, dengan periode yang lebih panjang diharapkan hasil yang diperoleh bisa lebih akurat dan lebih baik. Bagi perusahaanperusahaan yang terkait dalam penelitian ini diharapkan mampu memperhatikan kondisi internal ataupun eksternal perusahaan yang mana digunakan sebagai tolak ukur prospek usaha perusahaan agar bisa menghasilkan keuntungan yang lebih baik lagi untuk kedepannya.

\section{REFERENSI}

Akbar, S.P dan H. Usman. 2006. Metode Penelitian Sosial. Jakarta: Bumi Aksara.

Arisona,V. F. 2013. Faktor-Faktor yang Mempengaruhi Price Earning Ratio pada Indeks LQ45 di Bursa Efek Indonesia. Jurnal Ilmu Manajemen, Vol1 (1), 103-112.

Arista, D.. 2012. Analisis Faktor-Faktor yang Mempengaruhi Return Saham pada Perusahaan Manufaktur yang Go public di BEI periode tahun 2005-2009, Jurnal IImu Manajemen dan Akuntansi, Vol $3(1)$.

Azli, M. N. dan Azizi, N. 2009. Pelaporan Kewangan Menerusi Internet: Perspektif Teori Kontingensi Jurnal Kemanusiaan, Vol 14.

Brigham, E . F. dan Houston, J. F. 2011. Dasar-dasar Manajemen Keuangan Terjemahan. Edisi 10. Jakarta: Salemba Empat.

Darmadji, F. 2012. Pasar Modal Indonesia. Jakarta: Salemba Empat.

Fahmi, I. 2012. Analisis Laporan Keuangan. Cetakan Ke-2. Bandung: Alfabeta.

Ghozali, I. 2013. Aplikasi Analisis Multivariate Dengan Program IBM SPSS 21 Update PLS Regresi. Edisi 7. Semarang : Badan Penerbit Universitas Diponegoro.

Haryadi, R. M., dan Nuraeni, E. A. L. 2016. Pengaruh Leverage, Profitability, Market Value dan Ukuran Perusahaan terhadap Nilai Perusahaan Property yang Terdaftar di Bei Tahun 2012-2014. Ekonomia, Vol5(3).

Haryati, W., dan Ayem, S. 2014. Pengaruh Return On Assets, Debt To Equity Ratio, Dan Earning Per Share Terhadap Nilai Perusahaan (Studi Kasus Pada Perusahaan Food And Beverages Yang Terdaftar Di Bei Periode 2009-2011). Jurnal Akuntansi, Vol 2(1), 43-55.

Indriantoro, N., dan Supomo, B. 2009. Metodologi Penelitian Bisnis untuk Akuntansi dan Manajemen, Edisi Pertama. Yogyakarta : BPFE Yogyakarta.

Jensen, M. C. dan Smith, C. H. 1984. The Modern Theory of Corporate Finance. McGraw-Hill.

Kasmir, 2013. Analisis laporan Keuangan cetakan keenam, Jakarta: Penerbit PT.Raja Grafindo.

Mardiyanto, H. 2009. Intisari Manajemen Keuangan. Jakarta : Grasindo 
Meilani, S. 2014. Pengaruh Dividend Payout Ratio (DPR), Debt Equity Ratio (DER), Return On Asset (ROA), Dan Size Perusahaan Terhadap Nilai Perusahaan Pada Perusahaan Manufaktur Yang Terdaftar Di Bursa Efek Indonesia (BEI) Periode 2009-2012.

Mindra, S., dan Erawati, T. 2014. Pengaruh earning Per Share (EPS), Ukuran Perusahaan, Profitabilitas, dan Leverage terhadap Nilai Perusahaan (Studi Kasus pada Perusahaan Manufaktur yang Terdaftar di Bursa Efek Indonesia pada Tahun 2009-2011). Jurnal Akuntansi, Vol2(2), 10-22

Pantow, M. S. R., Murni, S., dan Trang, I. 2015. Analisa Pertumbuhan Penjualan, Ukuran Perusahaan, Return On Asset, dan Struktur Modal Terhadap Nilai Perusahaan yang Tercatat di Indeks LQ 45. Jurnal EMBA: Jurnal Riset Ekonomi, Manajemen, Bisnis dan Akuntansi. Vol3(1).

Permana, F. G. 2010. Pengaruh kinerja keuangan dan ukuran perusahaan terhadap return saham perbankan yang terdaftar di bei tahun 2004-2008. Doctoral dissertation. Universitas Sebelas Maret.

Prasetyorini, B.F. 2013. Pengaruh Ukuran Perusahaan, Leverage, Price Earning Ratio Dan Profitabilitas Terhadap Nilai Perusahaan. Jurnal IImu Manajemen, Vol1(1).

Salvatore, D. 2005. Managerial Economics. Fifth Edition. Singapore: Thomson Learning.

Santoso, S. 2002. Buku Latihan SPSS Statistik Multivariant. Jakarta: Salemba Infotek.

Siregar, S. 2013. Metede penelitian Kuantitatif Dilengkapi Perbandingan Perhitungan Manual dan SPSS. Jakarta: Kencana Prenada Media Group.

Solihin, I. 2012. Manajemen Strategik, Penerbit Erlangga, Jakarta.

Sugiyono. 2014. Metode Penelitian Pendidikan Pendekatan Kuantitatif, Kualitatif, dan R\&D. Bandung: Alfabeta.

Syamsuddin, L. 2011. Manajemen Keuangan Perusahaan. Jakarta: Rajawali Pers

Taswan. 2010. Manajemen Perbankan, Konsep, Teknik, dan Aplikasi. Edisi Kedua. Yogyakarta : UPP STIM YKPN.

Wiagustini, L.P. 2014. Dasar-dasar Manajemen Keuangan. Denpasar: Udayana University Press.

Widoatmodjo, S. 2012. Cara Sehat Investasi di Pasar Modal. Edisi Revisi. Jakarta: PT. Jurnalindo Aksara Grafika.

Wulandari, C. 2015. Analisis Pengaruh Return On Assets (ROA), Earning Per Share (EPS), Debt to Equity Ratio (DER) Terhadap Price to Book Value (PBV) Pada Perusahaan Manufaktur (Studi kasus Perusahaan Food and Beverages yang terdaftar di BEI Tahun 2010-2013). Doctoral Dissertation. Universitas Muhammadiyah Surakarta. 